\title{
Phytoprotection
}

\section{Response of the Pacific Coast wireworm, Limonius canus, and the dusky wireworm, Agriotes obscurus (Coleoptera: Elateridae), to insecticide-treated wheat seeds in a soil bioassay Réponse du taupin du Pacifique, Limonius canus, et du taupin obscur, Agriotes obscurus (Coleoptera : Elateridae), à des semences de blé traitées à l'insecticide dans un test biologique dans le sol}

\author{
Willem G. van Herk, Robert S. Vernon, Chandra Moffat et Chantelle Harding
}

Volume 89, numéro 1, avril 2008

URI : https://id.erudit.org/iderudit/000378ar

DOI : https://doi.org/10.7202/000378ar

\section{Aller au sommaire du numéro}

Éditeur(s)

Société de protection des plantes du Québec (SPPQ)

ISSN

0031-9511 (imprimé)

1710-1603 (numérique)

Découvrir la revue

Citer cet article

van Herk, W. G., Vernon, R. S., Moffat, C. \& Harding, C. (2008). Response of the Pacific Coast wireworm, Limonius canus, and the dusky wireworm, Agriotes obscurus (Coleoptera: Elateridae), to insecticide-treated wheat seeds in a soil bioassay. Phytoprotection, 89(1), 7-19. https://doi.org/10.7202/000378ar

\section{Résumé de l'article}

Des larves du taupin obscur, Agriotes obscurus, et du taupin du Pacifique, Limonius canus, ont été exposées à des semences de blé germées et traitées à l'insecticide dans un dispositif-fenêtre rempli de terre en 2005 et en 2006. La position des larves ainsi que leur comportement envers les semences (contact ou répulsion) ont été observés toutes les 5 min durant 3 ou $5 \mathrm{~h}$. La santé des larves a été observée durant 70 ou 126 j après l'exposition. Les semences ont été traitées avec les fongicides Dividend XLRTA (difénoconazole, méfénoxame) ou Raxil MD (tébuconazole, métalaxyle), ou encore avec les insecticides Vitavax Dual (lindane), Poncho 600F (clothianidine), Cruiser 350FS (thiaméthoxame), Admire 240FS (imidaclopride), Gaucho 480FL (imidaclopride), Tefluthrin 20CS (téfluthrine), ou une combinaison Tefluthrin-Cruiser. La plupart des vers fil-de-fer (> $80 \%$ ) sont entrés en contact avec les semences dans tous les traitements. Ils sont généralement demeurés en contact avec les semences durant toute la période d'observation dans les traitements témoins (Dividend, Raxil, semences non traitées). Les larves ont été repoussées après un bref contact ( $<20 \mathrm{~min}$ ) dans tous les traitements de Tefluthrin, sauf si elles étaient moribondes. La majorité des vers fil-de-fer se sont remis de la morbidité induite par le contact avec les semences à l'intérieur de $21 \mathrm{~h}$ et n'ont pas fait de rechute, à l'exception des larves de $L$. canus exposées au Cruiser et de quelques larves de A. obscurus exposées aux insecticides Gaucho et Admire. Le taux de mortalité était bas ( $<50 \%$ ) dans tous les traitements sauf pour les larves de $L$. canus exposées au Cruiser à 15 et $30 \mathrm{~g}$ m.a. 100 kg-1 graine (60 et $75 \%$, respectivement). Le taux de mortalité était significativement plus bas lorsque les larves de $L$. canus étaient exposées à des combinaisons Tefluthrin-Cruiser que lorsqu'elles étaient exposées seulement au Cruiser. Ces résultats suggèrent que pour évaluer l'efficacité des insecticides à lutter contre les populations de vers fil-de-fer, une observation directe de leur comportement ainsi qu'une évaluation à long terme de leur état de santé sont nécessaires. L’impact de la répulsion et de la morbidité causées par les insecticides sur la lutte aux vers fil-de-fer dans les champs est également abordé. 


\title{
Response of the Pacific Coast wireworm, Limonius canus, and the dusky wireworm, Agriotes obscurus (Coleoptera: Elateridae), to insecticide-treated wheat seeds in a soil bioassay
}

\author{
Willem G. van Herk, Robert S. Vernon, Chandra Moffat, and Chantelle Harding \\ Received 2008-07-23; accepted 2008-10-17
}

PHYTOPROTECTION 89 : 7-19

\begin{abstract}
Larvae of the dusky wireworm, Agriotes obscurus, and the Pacific Coast wireworm, Limonius canus, were exposed to germinated, insecticide-treated wheat seeds in a soil-filled bioassay in 2005 and 2006. Position in the bioassay and contact and/or repellence behaviour towards the seeds were recorded every $5 \mathrm{~min}$ for 3 or $5 \mathrm{~h}$. Wireworm health was recorded for 70 or $126 \mathrm{~d}$ after exposure. Seeds were treated with the fungicides Dividend XLRTA (difenoconazole, mefenoxam) or Raxil MD (tebuconazole, metalaxyl), and/or the insecticides Vitavax Dual (lindane), Poncho 600F (clothianidin), Cruiser 350FS (thiamethoxam), Admire 240FS (imidacloprid), Gaucho 480FL (imidacloprid), Tefluthrin 20CS (tefluthrin), or Tefluthrin-Cruiser combinations. Most wireworms (>80\%) came into contact with the seeds in all treatments. Wireworms generally remained in contact throughout the observation period in the control treatments (Dividend, Raxil, untreated seeds). Unless moribund, wireworms were repelled after brief $(<20 \mathrm{~min}$ ) contact in all Tefluthrin treatments. Most wireworms recovered from contact-induced morbidity within $21 \mathrm{~d}$ and did not relapse, except $L$. canus exposed to Cruiser and some $A$. obscurus exposed to Gaucho and Admire. Wireworm mortality was low (<50\%) in all treatments except $L$. canus exposed to Cruiser at 15 and $30 \mathrm{~g}$ a.i. $100 \mathrm{~kg}^{-1}$ seed (60 and 75\%, respectively). Mortality was significantly less important when L. canus larvae were exposed to Tefluthrin-Cruiser combinations than when exposed to Cruiser alone. We suggest that efficacy assessments of insecticides for wireworm control require direct observation of their behaviour and long-term post-exposure health assessments, and discuss the impact of repellence and/or morbidity elicited by insecticides on wireworm control in the field.
\end{abstract}

Keywords: Agriotes obscurus, insecticide, Limonius canus, repellence, seed treatments, wireworm.

[Réponse du taupin du Pacifique, Limonius canus, et du taupin obscur, Agriotes obscurus (Coleoptera : Elateridae), à des semences de blé traitées à l'insecticide dans un test biologique dans le sol]

Des larves du taupin obscur, Agriotes obscurus, et du taupin du Pacifique, Limonius canus, ont été exposées à des semences de blé germées et traitées à l'insecticide dans un dispositif-fenêtre rempli de terre en 2005 et en 2006. La position des larves ainsi que leur comportement envers les semences (contact ou répulsion) ont été observés toutes les 5 min durant 3 ou $5 \mathrm{~h}$. La santé des larves a été observée durant 70 ou 126 j après l'exposition. Les semences ont été traitées avec les fongicides Dividend XLRTA (difénoconazole, méfénoxame) ou Raxil MD (tébuconazole, métalaxyle), ou encore avec les insecticides Vitavax Dual (lindane), Poncho 600F (clothianidine), Cruiser 350FS (thiaméthoxame), Admire 240FS (imidaclopride), Gaucho 480FL (imidaclopride), Tefluthrin 20CS (téfluthrine), ou une combinaison TefluthrinCruiser. La plupart des vers fil-de-fer (>80\%) sont entrés en contact avec les semences dans tous les traitements. Ils sont généralement demeurés en contact avec les semences durant toute la période d'observation dans les traitements témoins (Dividend, Raxil, semences non traitées). Les larves ont été repoussées après un bref contact $(<20 \mathrm{~min})$ dans tous les traitements de Tefluthrin, sauf si elles étaient moribondes. La majorité des vers fil-de-fer se sont remis de la morbidité induite par le contact avec les semences à l'intérieur de $21 \mathrm{~h}$ et n'ont pas fait de rechute, à l'exception des larves de $L$. canus exposées au Cruiser et de quelques larves de $A$. obscurus exposées aux insecticides Gaucho et Admire. Le taux de mortalité était bas $(<50 \%)$ dans tous les traitements sauf pour les larves de $L$. canus exposées au Cruiser à 15 et $30 \mathrm{~g} \mathrm{~m}$.a. $100 \mathrm{~kg}^{-1}$ graine (60 et $75 \%$, respectivement). Le taux de mortalité était significativement plus bas lorsque les larves de $L$. canus étaient exposées à des combinaisons Tefluthrin-Cruiser que lorsqu'elles étaient exposées seulement au Cruiser. Ces résultats suggèrent que

Agriculture and Agri-Food Canada, Pacific Agri-Food Research Centre, 6947 Highway 7, P.O. Box 1000, Agassiz, British Columbia, Canada V0M 1A0; corresponding author e-mail: vanherkw@agr.gc.ca 
pour évaluer l'efficacité des insecticides à lutter contre les populations de vers fil-de-fer, une observation directe de leur comportement ainsi qu'une évaluation à long terme de leur état de santé sont nécessaires. L'impact de la répulsion et de la morbidité causées par les insecticides sur la lutte aux vers fil-de-fer dans les champs est également abordé.

Mots clés: Agriotes obscurus, insecticide, Limonius canus, répulsion, taupin, traitements de semences.

\section{INTRODUCTION}

Wireworms are important pests of wheat, vegetable and soft fruits in both North America and Europe (Vernon 2005; Parker and Howard 2001), and are likely to become an even more serious problem in some countries as effective organochlorine (OC), organophosphate (OP) and carbamate insecticides are being removed without the promise of suitable replacements (Grove et al. 2000; Vernon et al. 2001). The search for lower-risk replacement chemicals has so far focused on pyrethroid (i.e. tefluthrin, bifenthrin), chloronicotinoid (i.e. imidacloprid, acetamiprid), thianicotinoid (i.e. clothianidin, thiamethoxam) and phenyl pyrazole (i.e. fipronil) insecticides (Parker and Howard 2001), some of which have demonstrated their effectiveness against wireworms and are being used for wireworm management (Kuhar et al. 2003; Parker and Howard 2001). Recent reports suggest that imidacloprid and thiamethoxam are effective against Agriotes sp. and Melanotus sp. in corn and sugarbeet (Andersch and Schwarz 2003; Maienfisch et al. 2001; Pons and Albajes 2002), and that clothianidin is more effective against Melanotus sp. in corn than either chlorpyrifos or tefluthrin (Andersch and Schwarz 2003). However, these assessments are based on plant establishment and/or yield and do not consider the direct effects of these chemicals on wireworm health and behaviour.

The direct effects of insecticides on wireworm health and behaviour are of interest and importance for several reasons. Recent toxicology work has shown that wireworms can recover from long-term (> $150 \mathrm{~d}$ ) morbidity induced by dermal exposure to imidacloprid, clothianidin and thiamethoxam (van Herk et al. 2008a; Vernon et al. 2008). In addition, certain insecticides are suspected to have repellent as well as toxic effects on wireworms, including aldrin and lindane (Long and Lilly 1958; Toba et al. 1988), terbufos (Belcher and Tenne 1987), and chlorpyrifos and fonofos (Horne and Horne 1991; Missionnier and Brunel 1979). Recent work by van Herk et al. (2008b) showed that the dusky wireworm, Agriotes obscurus L., was repelled by droplets of tefluthrin, chlorpyrifos, lindane and imidacloprid in a soil-less bioassay.

To determine if some of the neonicotinoid and synthetic pyrethroid insecticides listed above elicit repellence in wireworms when incorporated into soil, van Herk and Vernon (2007a) developed a bioassay that makes it possible to observe wireworm orientation, contact and repellence behaviours in response to insecticide-treated wheat seeds in soil. Repellence, generally defined as movement away from a stimulus (Dethier et al. 1960), is here said to occur when wireworms retreat $>5 \mathrm{~cm}$ from the seeds within $30 \mathrm{~min}$ of contact (van Herk and Vernon 2007a).

Preliminary studies using this assay indicated that larvae of both $A$. obscurus and the Pacific Coast wireworm, Limonius canus LeConte, were repelled by Tefluthrin-treated wheat seeds in soil (van Herk and Vernon 2007a). However, this report did not include wireworm response to seeds treated with commercial formulations of thiamethoxam, clothianidin and imidacloprid, or the effect(s) of repeated contact with insecticide-treated seeds, i.e. whether it elicited a change in contact and foraging behaviour or resulted in aversion learning. These questions are of interest as some neonicotinoid insecticides may elicit repellence in wireworms (as discussed above), and because behavioural resistance to insecticides resulting from aversion learning is a common and important resistance mechanism (Bernays and Chapman 1987; Lockwood et al. 1984; Sparks et al. 1989).

Three observation studies were conducted using larvae of $A$. obscurus (in 2005) and L. canus (in 2005 and 2006) to determine wireworm response to seeds treated with thiamethoxam, clothianidin and imidacloprid, to determine whether exposure to both tefluthrin and thiamethoxam resulted in greater mortality than exposure to seeds treated with either chemical singly (as suggested by preliminary work by van Herk and Vernon; unpublished), and to determine if repeated contact with tefluthrin-treated seeds elicited a behavioural change. In the 2005 studies, both species were exposed to wheat seeds treated with lindane, tefluthrin or clothianidin, and $A$. obscurus larvae were also exposed to seeds treated with imidacloprid, thiamethoxam, and thiamethoxam and tefluthrin combined. In the 2006 study, L. canus larvae were exposed to seeds treated with lindane and different concentrations of tefluthrin, thiamethoxam, and tefluthrin plus thiamethoxam. In this paper we describe the effects of these insecticide treatments on wireworm behaviour, morbidity and mortality.

\section{MATERIALS AND METHODS}

\section{Wireworms}

Agriotes obscurus larvae used in the 2005 study were collected by hand-sifting soil taken from pastureland in 2005 at the Pacific Agri-Food Research Centre (PARC) in Agassiz, BC. Collected larvae represented all instars, but were considered as belonging to one population since they were collected within $100 \mathrm{~m}$ of each other. Limonius canus larvae used in the 2005 study were collected using flour baits placed in a fallowed field at an organic farm in Kelowna, BC, in June 2005, while L. canus larvae used in the 2006 study were collected similarly from the same location in June 2006. Virtually all collected larvae were late instar (i.e. > $15 \mathrm{~mm}$ long) and were considered as belonging to one population since they were collected within $50 \mathrm{~m}$ of each other. All wireworms were stored at $4^{\circ} \mathrm{C}$ in $40 \mathrm{~L}$ Rubbermaid (Rubbermaid, Atlanta, GA) tubs filled with sandy-clay loam soil 
collected at PARC, until needed. To reduce variability, only late-instar feeding wireworms were used in the bioassays. Feeding wireworms were obtained by placing potato slices in the storage tubs. Wireworms assembled at the potato baits were then isolated in soil without food following methods described by van Herk and Vernon (2007a), and were used in bioassays within $3 \mathrm{~d}$.

\section{Bioassay}

Wireworms were exposed to germinated wheat seeds in soil-filled circular bioassays as described by van Herk and Vernon (2007a). Using circular bioassays ensures that wireworms moving along the edge of the arena (a common pre-orienting behaviour) remain within $13 \mathrm{~cm}$ from the seeds and do not become trapped in corners. Bioassay arenas consisted of three separate $30 \mathrm{~cm} \times 30 \mathrm{~cm}$ sections of transparent, $4 \mathrm{~mm}$ thick Plexiglas ${ }^{\circledR}$ connected by small carriage bolts. A $26 \mathrm{~cm}$ diam hole machined into the centre section created a circular chamber that could be filled with soil to a depth of $4 \mathrm{~mm}$. A transparent plastic grid overlaying both the top and bottom sections divided the chamber into 113 equallysized cells that were grouped into eight concentric rings and four quadrants. Rings and cells were numbered from the centre outwards, with ring 1 consisting of a single cell (cell 1) touching all four quadrants; other cells were restricted to individual quadrants. Five wheat seeds (cv. AC Superb) were placed in cell 1 after the bioassay chamber had carefully been filled with an even $4 \mathrm{~mm}$ layer of screened, sandy-clay loam soil. Soil used was adjusted to contain $20 \%$ moisture by weight. Wheat seeds were pre-germinated for $44-48 \mathrm{~h}$ at $25 \pm 1^{\circ} \mathrm{C}$ on moist paper towels, ensuring approximately $15 \mathrm{~mm}$ shoot length prior to bioassays. Seedlings were placed in ring 1; seedling shoots extended partly into ring 2 (cells $2-5$ ).

After the seeds were placed, the top section of the bioassay was put into place and fastened. Arenas were positioned horizontally on a raised wooden frame to make observations possible through both the top and bottom sections. Seedlings were allowed to grow in the soil in the assembled bioassay for 30 min to establish $\mathrm{CO}_{2}$ gradients (Doane et al. 1975), after which wireworms (one per arena) were introduced head first into the bioassay chamber through a $5 \mathrm{~mm}$ hole in the top centre of either cell 89, 96, 103 or 110 (the centre cells of ring 8 in quadrants I, II, III and IV, respectively). The wireworm introduction hole was sealed with pressure-sensitive tape (VWR International Ltd., Delta, BC) throughout the seed incubation and wireworm observation periods, and opened only for wireworm insertion ( $<1 \mathrm{~min}$ ).

Wireworm position in the bioassay, contact and/or repellence behaviour towards the seed, and health (if abnormal) were recorded every $5 \mathrm{~min}$ for $3 \mathrm{~h}$ in 2005 and for $5 \mathrm{~h}$ in 2006. Wireworms were considered to have come into contact with the seeds when they were within rings 1 or 2 of the bioassay (van Herk and Vernon 2007a). The duration of contact was estimated by multiplying the number of observed contact events by $5 \mathrm{~min}$, i.e. the interval between observations. For the 2006 study, wireworms were observed long enough to assess two or more contact periods and to measure the duration between these contact periods (hereafter referred to as 'inter-contact' periods). All observations were conducted at room temperature $\left(21 \pm 1^{\circ} \mathrm{C}\right)$ under low intensity red light $\left(0.75 \mu \mathrm{E} \mathrm{s}^{-1} \mathrm{~m}^{-2}\right.$, measured with a $\mathrm{Li}-188 \mathrm{~B}$ integrating quantum radiometer/photometer; Li-Cor, Lincoln, NB).

Post-exposure wireworm health was assessed immediately after bioassays using methods and criteria developed by Vernon et al. (2008). Wireworms that could move out of an $8 \mathrm{~cm}$ diam circle drawn on 12.5 $\mathrm{cm}$ filter paper in Petri dish arenas within 2 min were designated as 'alive'. Wireworms that were incapable of directed movement but were capable of body movements obvious to the naked eye were designated as 'writhing'. Wireworms that made no visible body movements with or without prodding were inspected under a dissecting microscope to determine if they exhibited leg and/or mouthpart movements. These wireworms were designated as 'appendage movement'. Wireworms exhibiting no spontaneous or elicited writhing or leg/mouthpart movements were temporarily classified as 'probably dead', but were not recorded as 'dead' until they showed signs of decomposition (Vernon et al. 2008). Wireworms were stored individually into $150 \mathrm{~mL}$ plastic containers (Fisher Scientific, Whitby, ON) with screened soil (as described above) for $70 \mathrm{~d}$ after exposure (DAE) in the 2005 studies, and for $126 \mathrm{DAE}$ in 2006. Wireworm health was assessed 1 and 7 DAE, and weekly thereafter. For the 2006 study, wireworm health was also assessed 3 DAE. Mortality was compared among treatments at 56 DAE in the 2005 studies and at 70 DAE in the 2006 study, after which time no further mortality was observed.

\section{Insecticide treatments}

Wheat seeds used in the 2005 studies were treated with Vitavax Dual (containing $50 \mathrm{~g}$ lindane and $54 \mathrm{~g}$ carbathiin) at $124 \mathrm{~g}$ a.i. $100 \mathrm{~kg}^{-1}$ seed, Gaucho $480 \mathrm{FL}$ (imidacloprid) at $15 \mathrm{~g}$ a.i. $100 \mathrm{~kg}^{-1}$ seed, Admire 240FS (imidacloprid) at 10 and $30 \mathrm{~g}$ a.i. $100 \mathrm{~kg}^{-1}$ seed, Poncho $600 \mathrm{~F}$ (clothianidin) at $25 \mathrm{~g}$ a.i. $100 \mathrm{~kg}^{-1}$ seed, Tefluthrin 20CS (tefluthrin) at $10 \mathrm{~g}$ a.i. $100 \mathrm{~kg}^{-1}$ seed, Cruiser $350 \mathrm{FS}$ (thiamethoxam) at 10 and $30 \mathrm{~g}^{\text {a.i. }} 100 \mathrm{~kg}^{-1}$ seed, and a combination of Cruiser 350FS and Tefluthrin 20CS (both at $10 \mathrm{~g}$ a.i. $100 \mathrm{~kg}^{-1}$ seed) (Table 1). Wheat seeds treated with Poncho and Gaucho were treated by Gustafson Inc. (now Bayer CropScience Canada, Toronto, ON), and were also treated with the fungicide Raxil MD (1.5 g a.i. tebuconazole and $2.0 \mathrm{~g}$ a.i. metalaxyl $100 \mathrm{~kg}^{-1} \mathrm{seed}$ ). Seeds treated with Vitavax Dual, Tefluthrin and/or Cruiser were treated by Syngenta Crop Protection Canada Inc. (Guelph, ON) and, except for Vitavax Dual, were also treated with the fungicide Dividend XLRTA (containing $3.21 \%$ difenoconazole and $0.27 \%$ mefenoxam) at $13 \mathrm{~g}$ a.i. $100 \mathrm{~kg}^{-1}$ seed. These insecticide/fungicide combinations reflect treatments under evaluation for wireworm control by Bayer and Syngenta. Admire 240FS was applied to untreated seeds by the authors. In addition, untreated wheat seeds and seeds treated with Raxil MD and Dividend XLRTA alone were tested as control treatments. Due to limited wireworm availability, not all treatments were tested on both wireworm species in 2005 (Table 1). 
Table 1. Contact duration $(\mathrm{min})$ of $A$. obscurus and $L$. canus larvae exposed for $\mathbf{1 8 0} \mathbf{m i n}$ to wheat seeds treated with pesticides, proportion of moribund larvae at the end of the bioassay, and proportion of dead larvae in 2005

\begin{tabular}{|c|c|c|c|c|c|}
\hline Treatment $^{1}$ & $C(N)^{2}$ & $\begin{array}{l}\text { Mean (SEM) duration } \\
\text { of first contact } \\
\text { (min) }\end{array}$ & $\begin{array}{l}\text { Mean (SEM) duration } \\
\text { of total contact } \\
\text { (min) }\end{array}$ & $\begin{array}{l}\text { Proportion (of } \mathrm{C} \text { ) } \\
\text { moribund after } \\
\text { bioassays }\end{array}$ & $\begin{array}{c}\text { Proportion (of C) } \\
\text { dead at } \\
56 \mathrm{DAE}^{4}\end{array}$ \\
\hline \multicolumn{6}{|c|}{ Agriotes obscurus } \\
\hline Untreated & $26(29)$ & $122.7(11.4) \mathrm{a}^{3}$ & $128.1(10.3) \mathrm{a}$ & $0 \mathrm{a}$ & $0 \mathrm{a}$ \\
\hline Dividend & $19(20)$ & $112.4(15.0) a b$ & $127.6(10.8) \mathrm{a}$ & $0 \mathrm{a}$ & $0 \mathrm{a}$ \\
\hline Raxil & $19(22)$ & $90.0(14.8) a b c$ & $105.3(12.9) \mathrm{ab}$ & $0 \mathrm{a}$ & $0 \mathrm{a}$ \\
\hline Cruiser (10) & $20(20)$ & $104.5(9.9) \mathrm{ab}$ & $124.8(9.0) \mathrm{a}$ & $0.90 \mathrm{~cd}$ & $0.15 a b$ \\
\hline Cruiser (30) & $20(20)$ & $64.3(9.9) \mathrm{bc}$ & $88.0(8.9) a b c$ & $0.40 \mathrm{bc}$ & $0 \mathrm{a}$ \\
\hline Tefluthrin (10) & $20(24)$ & $15.5(1.9) \mathrm{d}$ & $48.0(7.6) \mathrm{cd}$ & $0.45 \mathrm{bc}$ & $0.05 a$ \\
\hline Cruiser (10) + Tefluthrin (10) & $20(25)$ & $13.8(2.1) \mathrm{d}$ & $34.5(5.6) \mathrm{d}$ & $0.35 \mathrm{~b}$ & $0.25 \mathrm{ab}$ \\
\hline Gaucho (15) & $18(20)$ & $79.4(16.2)$ abc & $100.6(13.0) a b$ & $0.83 \mathrm{bcd}$ & $0.22 \mathrm{ab}$ \\
\hline Admire (10) & $20(22)$ & 71.4 (13.3) abc & 79.5 (12.5) abcd & $0.75 \mathrm{bcd}$ & $0.45 \mathrm{~b}$ \\
\hline Admire (30) & $18(19)$ & 71.1 (14.3) abc & 74.7 (13.8) bcd & $0.72 \mathrm{bcd}$ & $0.39 \mathrm{~b}$ \\
\hline Poncho (25) & $18(20)$ & $50.3(10.3) \mathrm{cd}$ & $72.8(9.2) \mathrm{bcd}$ & $0.72 \mathrm{bcd}$ & $0.11 \mathrm{ab}$ \\
\hline Vitavax (124) & $20(20)$ & $113.8(13.0)$ ab & $115.3(12.4) a b$ & $1.0 \mathrm{~d}$ & $0.10 \mathrm{ab}$ \\
\hline \multicolumn{6}{|c|}{ Limonius canus } \\
\hline Untreated & $17(20)$ & $117.4(16.8) \mathrm{a}$ & $136.2(13.4) \mathrm{a}$ & $0.0 \mathrm{a}$ & $0 \mathrm{a}$ \\
\hline Dividend & $10(10)$ & $83.0(19.7) a b$ & $124.5(11.3) \mathrm{a}$ & $0.0 \mathrm{a}$ & $0 \mathrm{a}$ \\
\hline Raxil & $10(10)$ & $111.5(20.0) \mathrm{a}$ & $135.5(14.8) \mathrm{a}$ & $0.0 \mathrm{a}$ & $0 \mathrm{a}$ \\
\hline Tefluthrin (10) & $20(20)$ & $21.3(3.0) \mathrm{c}$ & $36.8(3.9) \mathrm{c}$ & $0.4 \mathrm{~b}$ & $0 \mathrm{a}$ \\
\hline Poncho (25) & $17(19)$ & $45.9(7.6) \mathrm{bc}$ & $63.5(10.0) \mathrm{bc}$ & $0.53 \mathrm{~b}$ & $0.11 \mathrm{a}$ \\
\hline Vitavax (124) & $19(20)$ & 56.1 (14.4) bc & $91.8(12.8) a b$ & $0.68 \mathrm{~b}$ & $0.15 a$ \\
\hline
\end{tabular}

1 Dividend = Dividend XLRTA, Raxil = Raxil MD, Cruiser = Cruiser 350FS, Tefluthrin = Tefluthrin 20CS, Gaucho = Gaucho 480FL, Admire $=$ Admire 240FS, Poncho $=$ Poncho 600F, Vitavax $=$ Vitavax Dual. Numbers in parentheses indicate grams a.i. $100 \mathrm{~kg}^{-1}$ seed .

${ }^{2} \mathrm{C}=$ number of wireworms that came into contact with the seeds; $\mathrm{N}=$ number of wireworms that were exposed.

${ }^{3}$ Values followed by the same letter within a column are not significantly different at $\alpha=0.05$. Analyses were conducted separately per species.

${ }^{4} \mathrm{DAE}=$ days after exposure.

Wheat seeds used in the 2006 study were treated by Syngenta Crop Protection Canada Inc. with Vitavax Dual at $124 \mathrm{~g}$ a.i. $100 \mathrm{~kg}^{-1}$ seed, Tefluthrin 20CS, Cruiser 350FS, or both Tefluthrin 20CS and Cruiser 350FS. Tefluthrin 20CS and Cruiser 350FS were tested individually at $5,10,15,20$ and $30 \mathrm{~g}$ a.i. $100 \mathrm{~kg}^{-1}$ seed to determine if the concentration of either chemical affected wireworm behaviour. The combined Tefluthrin 20CS and Cruiser 350FS treatments were tested at 5, 10, 15 and $20 \mathrm{~g}$ a.i. $100 \mathrm{~kg}^{-1}$ seed of each insecticide to determine if using both chemicals on the seeds had an enhanced effect on wireworm behaviour and health. Seeds treated with Tefluthrin and/or Cruiser were also treated with the fungicide Dividend XLRTA at $13 \mathrm{~g}$ a.i. $100 \mathrm{~kg}-1$ seed.

Between 20 and 30 A. obscurus larvae were exposed to each treatment in 2005. Due to a shortage of $L$. canus in 2005 , only 10 wireworms were exposed to the Raxil and Dividend treatments. Depending on the availability of feeding wireworms, 20 to 60 L. canus larvae were exposed to each treatment in the 2006 study. Each treatment was conducted over several weeks, with several, randomly-chosen treatments assayed per day. Ten to twenty wireworms were observed concurrently on each observation day. As wireworms have long larval periods (approximately 6 mo per instar), can be maintained in storage for extensive periods (> $2 \mathrm{yr}$ ), and were handled similarly in all bioassays (i.e. similar storage condi- tions, selection and handling, bioassay preparation, observation methods), observation date was not considered to have an impact on wireworm behaviour.

These insecticides were chosen for study as they are currently being evaluated for wireworm management (see above) and as some (e.g. Poncho, Gaucho) appear to provide stand protection in wheat without reducing wireworm populations (R.S. Vernon, unpublished data). Of these insecticides, clothianidin (Poncho), thiamethoxam (Cruiser) and tefluthrin (Force 3.0G) are currently registered in Canada for wireworm management in corn; Vitavax Dual was also included as it has historically been used for wireworm management and is considered repellent to wireworms (Long and Lilly 1958; Toba et al. 1988).

\section{Statistical analysis}

The proportion of wireworms that came into contact with the seeds, or were moribund or dead at the end of the observation or health assessment periods, was compared among treatments with Chi-square analyses (Proc FREQ, SAS 9.1; SAS Institute Inc. 2002) followed by Ryan's test $(\alpha=0.05)$ to separate treatments (Ryan 1960). Mean contact and inter-contact durations were compared among treatments with ANOVA (Proc GLM, SAS 9.1) followed by the RyanEinot-Gabriel-Welsch multiple range test $(\alpha=0.05$ ) (Ramsey 1978); normality of data was assessed with Proc UNIVARIATE (SAS 9.1) and by plotting of data 
points and residuals. For selected treatments, comparisons between the two wireworm species exposed to the same insecticide in 2005, and between L. canus exposed to the same insecticide in 2005 and 2006, were made with $t$-tests (Proc TTEST, SAS 9.1) $(\alpha=0.05)$. Comparisons between the duration of the first and second contact periods were made for the same subset of wireworms with a paired sample $t$-test. Amongtreatment comparisons of the duration of three consecutive contact periods were made for a subset of treatments from the 2006 study that contained tefluthrin (i.e. treatments in which > 10 wireworms made three contacts) with a repeated measures ANOVA (Proc GLM). Comparisons between the two inter-contact periods were made with paired sample $t$-tests for these treatments.

\section{RESULTS}

\section{Duration of first contact}

For all three studies ( $A$. obscurus in 2005, L. canus in 2005 , and L. canus in 2006), a high percentage (> $80 \%$ ) of wireworms introduced into bioassay arenas came into contact with the seeds during the observation period (Tables 1 and 2), suggesting that insecticide treatments did not prevent wireworm movement towards, or contact with, the seeds. However, in each study, first contact duration differed significantly among treatments $\left(F_{11,227}=9.77, P<0.0001\right.$, Table 1 ; $F_{5,87}=8.61, P<0.0001$, Table $1 ; F_{16,478}=22.64, P<$ 0.0001 , Table 2), as the insecticides affected normal wireworm behaviour. In the 2006 L. canus study, poorer seed germination in untreated seeds and, to a lesser extent, in the Cruiser $20 \mathrm{~g}$ a.i. treatment also affected first contact duration. Seedlings in these two treatments had shorter roots (approx. 5-10 $\mathrm{mm}$, instead of $15 \mathrm{~mm}$ in the other treatments), likely because seeds were mistakenly given less moisture during pre-germination (Cruiser $20 \mathrm{~g}$ ) or were not treated with a fungicide (untreated seeds). All seeds used in the 2006 study came from the same lot and were treated at the same time, and the poorer germination seen in the above treatments does not suggest poorer germination in the field, though the absence of fungicide in the untreated seeds may cause a slight delay in emergence. However, poorer seed germination will affect seedling $\mathrm{CO}_{2}$ production, which may affect wireworm contact with the seeds since $\mathrm{CO}_{2}$ stimulates feeding in wireworms (Doane et al. 1975).

\section{Control treatments}

Agriotes obscurus larvae exposed to control treatments (untreated seeds or seeds treated with Dividend XLRTA or Raxil MD) remained in contact in an apparently healthy state for 122.7 (SEM $=11.4$ ), 112.4 (15.0) and 90.0 (14.8) min, respectively, with

Table 2. Contact duration ( $\mathrm{min}$ ) of $L$. canus larvae exposed for $\mathbf{3 0 0} \mathrm{min}$ to wheat seeds treated with insecticides, proportion of moribund larvae at the end of the bioassay, and proportion of dead larvae in 2006

\begin{tabular}{|c|c|c|c|c|c|c|c|}
\hline Treatment $^{1}$ & $\mathrm{C} 1(\mathrm{~N})^{2}$ & $\begin{array}{l}\text { Mean (SEM) } \\
\text { duration of } \\
\text { first contact } \\
\text { (min) }\end{array}$ & $\mathrm{C} 2^{4}$ & $\begin{array}{l}\text { Mean (SEM) } \\
\text { duration of } \\
\text { second contact } \\
\text { (min) }\end{array}$ & $\begin{array}{l}\text { Mean (SEM) } \\
\text { duration of } \\
\text { total contact } \\
\text { (min) }\end{array}$ & $\begin{array}{l}\text { Proportion } \\
\quad \text { (of } \mathrm{C} 1 \text { ) } \\
\text { moribund after } \\
\text { bioassays }\end{array}$ & $\begin{array}{c}\text { Proportion } \\
\text { (of } \mathrm{C} 1 \text { ) } \\
\text { dead at } \\
70 \mathrm{DAE}^{5}\end{array}$ \\
\hline Untreated & $33(40)$ & $118.0(19.1) b^{3}$ & 17 & $70.3(16.4) \mathrm{bc}^{3}$ & $183.6(14.8) a^{3} b^{3}$ & $0 a^{3}$ & $0.06 a b^{3}$ \\
\hline Dividend & $40(40)$ & $182.4(18.0) \mathrm{a}$ & 13 & $126.8(28.2) \mathrm{a}$ & $232.1(11.2) \mathrm{a}$ & $0 \mathrm{a}$ & $0.05 a b$ \\
\hline Cruiser (5) & $20(20)$ & $171.3(21.1) a b$ & 11 & $75.9(24.3) \mathrm{b}$ & $230.0(11.8) \mathrm{a}$ & 0 a & $0.25 \mathrm{bc}$ \\
\hline Cruiser (10) & $37(40)$ & $141.2(13.8) a b c$ & 19 & $62.1(16.7) \mathrm{bcd}$ & $176.6(12.8) a b$ & $0.05 a b$ & $0.35 \mathrm{~cd}$ \\
\hline Cruiser (15) & $20(20)$ & $156.5(17.2) a b c$ & 13 & $37.7(13.1) \mathrm{bcd}$ & $203.5(15.8) a b$ & $0.35 \mathrm{bcd}$ & $0.60 \mathrm{de}$ \\
\hline Cruiser (20) & $33(40)$ & $106.5(14.5) \mathrm{c}$ & 25 & $63.0(12.0) \mathrm{bcd}$ & $165.8(14.6) b$ & $\mathrm{n} / \mathrm{a}$ & $\mathrm{n} / \mathrm{a}$ \\
\hline Cruiser (30) & $20(20)$ & $98.3(13.4) \mathrm{c}$ & 16 & $54.7(12.5) \mathrm{bcd}$ & $157.0(15.4) \mathrm{b}$ & $0.35 \mathrm{bcd}$ & $0.75 \mathrm{e}$ \\
\hline Tefluthrin (5) & $54(60)$ & $25.3(2.5) \mathrm{d}$ & 40 & $25.0(4.3) \mathrm{bcd}$ & $62.5(6.6) \mathrm{c}$ & $0.19 \mathrm{abc}$ & $0.04 \mathrm{a}$ \\
\hline Tefluthrin (10) & $53(59)$ & $22.5(1.6) \mathrm{d}$ & 42 & $20.5(2.8) \mathrm{cd}$ & $61.9(5.8) \mathrm{c}$ & $0.19 a b c$ & $0.08 \mathrm{ab}$ \\
\hline Tefluthrin (15) & $18(18)$ & $27.2(4.5) \mathrm{d}$ & 18 & $31.4(11.0) \mathrm{bcd}$ & $82.8(14.6) \mathrm{c}$ & $0.28 \mathrm{abc}$ & $0 \mathrm{a}$ \\
\hline Tefluthrin (20) & $17(19)$ & $21.8(6.5) \mathrm{d}$ & 12 & $15.8(2.9) \mathrm{d}$ & $39.1(5.9) \mathrm{c}$ & $0.41 \mathrm{~cd}$ & $0 \mathrm{a}$ \\
\hline Tefluthrin (30) & $20(20)$ & $20.9(2.7) \mathrm{d}$ & 19 & $20.5(9.3) \mathrm{cd}$ & $64.5(9.4) \mathrm{c}$ & $0.20 \mathrm{abc}$ & $0.15 a b c$ \\
\hline $\begin{array}{l}\text { Cruiser }(5)+ \\
\text { Tefluthrin (5) }\end{array}$ & $20(20)$ & $27.5(3.9) \mathrm{d}$ & 17 & $22.4(4.5) \mathrm{cd}$ & $73.3(9.1) \mathrm{c}$ & $0.30 \mathrm{abc}$ & $0.05 a b$ \\
\hline $\begin{array}{l}\text { Cruiser }(10)+ \\
\text { Tefluthrin (10) }\end{array}$ & $20(20)$ & $23.5(3.5) \mathrm{d}$ & 20 & $18.0(2.0) \mathrm{d}$ & $68.3(10.4) \mathrm{c}$ & $0.15 a b c$ & $0.05 \mathrm{ab}$ \\
\hline $\begin{array}{l}\text { Cruiser (15) + } \\
\text { Tefluthrin (15) }\end{array}$ & $20(20)$ & $27.5(4.1) \mathrm{d}$ & 18 & $17.8(3.1) \mathrm{d}$ & $64.8(5.5) \mathrm{c}$ & $0.30 a b c$ & $0 \mathrm{a}$ \\
\hline $\begin{array}{l}\text { Cruiser }(20)+ \\
\text { Tefluthrin (20) }\end{array}$ & $17(19)$ & $31.5(4.0) \mathrm{d}$ & 14 & $15.7(3.4) \mathrm{d}$ & $59.1(6.6) \mathrm{c}$ & $0 \mathrm{a}$ & $0 \mathrm{a}$ \\
\hline Vitavax (124) & $53(60)$ & $98.6(12.3) \mathrm{c}$ & 32 & $46.9(6.9) \mathrm{bcd}$ & $147.5(11.0) \mathrm{b}$ & $0.74 \mathrm{~d}$ & $0 \mathrm{a}$ \\
\hline
\end{tabular}

\footnotetext{
Dividend = Dividend XLRTA, Cruiser = Cruiser 350FS, Tefluthrin = Tefluthrin 20CS, Vitavax = Vitavax Dual. Numbers in parentheses indicate grams a.i. $100 \mathrm{~kg}^{-1}$ seed.

${ }^{2} \mathrm{C} 1$ = number of wireworms that came into contact with the seeds at least once; $\mathrm{N}=$ number of wireworms exposed.

${ }^{3}$ Values followed by the same letter within a column are not significantly different at $\alpha=0.05$.

${ }^{4} \mathrm{C} 2$ = number of wireworms that came into contact with the seeds twice.

${ }^{5} \mathrm{DAE}=$ days after exposure.
} 
most wireworms still in contact at the end of the observation period (Table 1). Similarly, larvae of $L$. canus exposed to control treatments in 2005 remained in contact on average for 80 min or more, with most larvae still in contact at the end of the observation period (Table 1). In the 2005 studies, the initial contact duration of $A$. obscurus and $L$. canus exposed to untreated seeds and to seeds treated with either Dividend or Raxil was similar $(t=0.31, P=0.76$; $t=0.83, P=0.41 ; t=0.82, P=0.42$, respectively). First contact duration of $L$. canus with Dividend-treated seeds was longer in 2006 than in 2005 as bioassays were continued longer in 2006 than in 2005 and as normal wireworm feeding behaviour is to remain in contact with a suitable host for extensive periods (van Herk and Vernon 2007a). However, due to the poor seed germination in untreated seeds in the 2006 study (as discussed above), the first contact duration of $L$. canus exposed to untreated seeds was similar in the 2005 and 2006 studies.

\section{Tefluthrin 20SC}

The first contact duration of $A$. obscurus was shortest in the Tefluthrin treatments (with and without Cruiser), with wireworms moving away from seeds before showing signs of morbidity, often after $<10$ min contact (Table 1). Similarly, in 2005, L. canus remained in contact with Tefluthrin-treated seeds for a significantly shorter period than with seeds in the control treatments (Table 1). In the 2006 study, the first contact duration of $L$. canus was briefest in all Tefluthrin (with or without Cruiser) treatments, with no significant difference $(P>0.05)$ in contact duration among the treatments containing Tefluthrin (Table 2). First contact duration of $A$. obscurus and $L$. canus in the 2005 studies, and of $L$. canus exposed to seeds treated with Tefluthrin at $10 \mathrm{~g}$ a.i. in 2005 and 2006, did not differ significantly $(t=0.78, P=0.33 ; t=0.34$, $P=0.74$, respectively).

\section{Cruiser 350FS}

The first contact duration of Agriotes obscurus larvae exposed to Cruiser at $10 \mathrm{~g}$ a.i. (104.5 $\mathrm{min}, \mathrm{SEM}=9.9$ ) was the same as that of larvae exposed to control seeds (Table 1), partly because a high percentage $(50 \%)$ of wireworms became moribund and therefore stopped moving. Contact duration of Agriotes obscurus larvae exposed to Cruiser at $30 \mathrm{~g}$ a.i. was more brief ( $64.3 \mathrm{~min}, \mathrm{SEM}=9.9$ ) than that of larvae exposed to Cruiser at $10 \mathrm{~g}$ a.i., and fewer larvae (10\%) became moribund in situ. Exposure to seeds treated with both Tefluthrin and Cruiser resulted in significantly shorter contact duration than exposure to Cruiser alone (Table 1).

In the 2006 L. canus study, there was no significant difference $(P>0.05)$ between first contact duration of larvae exposed to seeds treated with Cruiser at 5, 10 and $15 \mathrm{~g}$ a.i., and control seeds (Table 2). As with $A$. obscurus, the first contact duration of $L$. canus larvae exposed to high rates of Cruiser (20-30 g a.i.) was significantly shorter than when the larvae were exposed to Dividend XLRTA (Table 2). In addition, contact duration of $L$. canus with seeds treated with Cruiser alone was significantly longer than with seeds treated with the same rates of both Cruiser and Tefluthrin (Table 2), indicating that the presence of
Tefluthrin decreased the duration of contact in the combined treatments.

\section{Vitavax Dual}

The first contact duration of Agriotes obscurus larvae exposed to Vitavax Dual (113.8 min, SEM = 13.0) was the same as that of larvae exposed to control seeds (Table 1), partly because most wireworms (90\%) became moribund in situ. In contrast, first contact duration of $L$. canus larvae exposed to Vitavax Dual in 2005 was shorter than that of $A$. obscurus exposed to the same treatment $(t=2.98, P=0.005)$, as fewer $L$. canus larvae (47\%) became moribund in situ. In the 2006 study, the first contact duration of L. canus was significantly shorter in the Vitavax Dual than in the Dividend treatments, as some wireworms $(30 \%)$ moved away from the seeds shortly before becoming moribund. While first contact in the Vitavax Dual treatment was significantly longer in 2006 than in $2005(t=2.23, P=0.03)$, this was due to the immobility of moribund wireworms and the longer observation periods in 2006 than in 2005.

\section{Other treatments}

Most $A$. obscurus that came into contact with seeds treated with Gaucho 480FL and Admire 240FS (at both 10 and $30 \mathrm{~g}$ a.i.) for the first time remained in contact for periods numerically but not significantly shorter than with control seeds (Table 1), and some wireworms became moribund in situ $(33,53$ and $37 \%$, respectively).

Contact duration of $A$. obscurus larvae exposed to Poncho 600F $25 \mathrm{~g}$ a.i. seeds was more brief (50.3 min, SEM $=10.3$ ) than that of larvae exposed to control seeds (Table 1 ), and a small percentage (25\%) of wireworms became moribund in situ. First contact duration of $A$. obscurus and $L$. canus ( $45.9 \mathrm{~min}, \mathrm{SEM}=7.6$ ) exposed to Poncho treatments was similar $(t=0.40$, $P=0.69$ ) (Table 1).

\section{Duration of subsequent contacts}

Some wireworms that had moved away from the seeds after the first contact subsequently re-contacted the seeds. In the 2005 studies, most $A$. obscurus $(95 \%)$ and $L$. canus $(80 \%)$ came into contact with seeds treated with Tefluthrin (alone) more than once. However, there was no significant difference between the duration of the first and second contacts [ $A$. obscurus: 15.0 (SEM = 2.0), $15.3(2.5) \mathrm{min}$, respectiveIy; $t=0.10, P=0.92$; L. canus: 20.3 (3.5), 13.8 (3.5) $\mathrm{min}$, respectively; $t=1.21, P=0.24$ ]. Similarly, most (85\%) $A$. obscurus re-contacted seeds treated with the Tefluthrin and Cruiser combination treatment, but there was no significant difference between the duration of the first and second contacts [14.7 (2.3), 15.6 (2.4) $\mathrm{min}$, respectively; $t=0.31, P=0.76$ ]. Not enough repeated contacts were observed in the other treatments to permit analysis (data not shown).

The longer observation periods in the 2006 study made it possible to observe repeated contacts with seeds in all treatments (Table 2). Duration of the second contact differed significantly among treatments $\left(F_{16,329}=6.91, P<0.0001\right)$, with contact with Dividend-treated seeds being significantly longer than with all other treatments, including untreated seeds (Table 2). As with the first contact, duration of 
the second contact was shortest in Tefluthrin treatments, and no significant difference in second contact duration was observed among Tefluthrin (plus Cruiser) treatments (Table 2).

Within-treatment comparisons between mean first and second contact durations (Table 2 ) indicated no significant difference $(P>0.05)$ when wireworms were exposed to Dividend or untreated seeds, or to treatments containing Tefluthrin, except for the Tefluthrin and Cruiser combination treatment at $20 \mathrm{~g}$ a.i. in which second contact duration was significantly shorter than the first $(t=3.01, P=0.005)$. Second contact duration was briefer than the first in the Vitavax Dual ( $t=3.67, P=0.0004)$, Cruiser at $5 \mathrm{~g}$ a.i. $(t=2.91, P=0.01), 10 \mathrm{~g}$ a.i. $(t=3.58, P=0.0007), 15 \mathrm{~g}$ a.i. $(t=5.51, P<0.0001), 20 \mathrm{~g}$ a.i. $(t=2.31, P=0.02)$ and $30 \mathrm{~g}$ a.i. ( $t=2.38, P=0.02)$ treatments, suggesting that these insecticides had an effect on $L$. canus contact behaviour.

To further explore this sublethal effect, first and second contact durations were compared within treatments for only those larvae that came into contact twice (data for the first contact period not shown for this subgroup). This comparison revealed no significant difference $(P>0.05)$ when wireworms were first exposed to Dividend, Vitavax Dual or Cruiser at 5, 10 and $30 \mathrm{~g}$ a.i. However, second contact was significantly shorter than first contact when wireworms were exposed to Cruiser at $15 \mathrm{~g}$ a.i. [first contact $=$ $141.9(15.6) \mathrm{min}$, second contact $=37.7(13.1) ; t=3.60$, $P=0.001$ ] and $20 \mathrm{~g}$ a.i. [first contact $=90.0(14.1)$, second contact $=63.0(12.0) ; t=2.46, P=0.02$ ], indicating that a single exposure to Cruiser could affect subsequent behaviour.

The effect of repeated contacts with Tefluthrin was assessed by within-treatment comparisons of the mean duration of the first, second and third contacts for $L$. canus larvae that made three or more contacts with seeds in the 2006 study (Table 3). This comparison indicated no significant difference $(P>0.05)$ in contact duration among treatments. Similarly, comparisons among different treatments for all first, all second and all third contact durations indicated no significant difference among treatments $(P>0.05)$. However, in all treatments (except Tefluthrin at $10 \mathrm{~g}$ a.i.), the second inter-contact interval was considerably longer than the first inter-contact interval (Table 3). While these differences were not statistically significant $(P>0.05)$, it may indicate that repeated contact with Tefluthrin had an effect on wireworm behaviour. Previous work has shown that even very brief ( $1 \mathrm{~min}$ ) contact with Tefluthrin-treated seeds will induce temporary morbidity in L. canus (van Herk and Vernon 2007b).

\section{Total contact duration}

Due to the repellence elicited by Tefluthrin, total contact duration in L. canus in the 2006 study differed significantly among treatments $\left(F_{16,478}=32.56, P<\right.$ 0.0001 ; Table 2). Contact in the Tefluthrin treatments was consistently shorter than in all other treatments, and the total contact duration in Cruiser (alone) treatments decreased as concentration increased, suggesting that when exposed to Cruiser, wireworm deterrence from contact increases with the concentration (Table 2).

Similarly, despite repeated contacts with seeds containing Tefluthrin (1-5 contacts), the total contact duration of $A$. obscurus remained lowest among these treatments over the $180-\mathrm{min}$ observation period $\left(F_{11,227}=8.56, P<0.0001\right.$; Table 1$)$, and it was significantly lower than in the control, Cruiser at $10 \mathrm{~g}$ a.i., Gaucho and Vitavax Dual treatments. In 2005, total contact duration of $L$. canus over the observation period differed significantly among treatments $\left(F_{5,87}\right.$ $=14.18, P<0.0001$; Table 1$)$, with total contact duration in the Tefluthrin and Poncho treatments being significantly shorter than in the control treatments (Table 1).

\section{Post-contact wireworm health and mortality}

There were significant differences among treatments in the proportion of larvae of $A$. obscurus, $L$. canus in 2005 and $L$. canus in 2006 that were moribund at the end of the observation period $\left(\chi^{2}=119.7\right.$, df $=11$, $P<0.0001$, Table 1; $\chi^{2}=32.87$, df $=5, P<0.0001$, Table 1; $\chi^{2}=128.81$, df $=15, P<0.0001$, Table 2). There were significant differences among treatments in the proportion of dead larvae at $56 \mathrm{DAE}$ in $A$. obscurus $\left(\chi^{2}=42.72, \mathrm{df}=11, P<0.0001\right)$, but not in the 2005 L. canus study $\left(X^{2}=8.65, \mathrm{df}=5, P=0.12\right)$.

Table 3. Contact and inter-contact durations $(\min )$ of $L$. canus larvae exposed to wheat seeds in the 2006 study for wireworms that came into contact with seeds treated with Tefluthrin 20SC (and Cruiser 350FS) three times during a 300-min observation period

\begin{tabular}{|c|c|c|c|c|c|c|}
\hline Insecticide ${ }^{1}$ & $\mathrm{C}^{2}$ & $\begin{array}{l}\text { Mean (SEM) } \\
\text { first contact }\end{array}$ & $\begin{array}{l}\text { Mean (SEM) } \\
\text { second contact }\end{array}$ & $\begin{array}{l}\text { Mean (SEM) } \\
\text { third contact }\end{array}$ & $\begin{array}{c}\text { Mean (SEM) } \\
\text { first } \\
\text { inter-contact } \\
\text { period }\end{array}$ & $\begin{array}{c}\text { Mean (SEM) } \\
\text { second } \\
\text { inter-contact } \\
\text { period }\end{array}$ \\
\hline Tefluthrin (5) & 23 & $20.4(2.5)$ & $20.4(3.1)$ & $22.4(4.2)$ & $47.2(7.8)$ & $57.2(9.7)$ \\
\hline Tefluthrin (10) & 32 & $22.0(2.2)$ & $20.8(3.6)$ & $19.2(4.7)$ & $51.4(10.0)$ & $48.8(9.1)$ \\
\hline Tefluthrin (15) & 13 & $24.2(4.0)$ & $25.0(10.7)$ & $15.0(1.7)$ & $32.7(10.1)$ & $59.2(12.4)$ \\
\hline Tefluthrin (30) & 13 & $20.5(2.2)$ & $24.6(13.5)$ & $20.2(2.2)$ & $35.5(10.7)$ & $69.2(13.5)$ \\
\hline Cruiser (5) + Tefluthrin (5) & 12 & $29.6(4.8)$ & $18.3(3.7)$ & $29.2(8.2)$ & $40.0(11.4)$ & $66.7(12.9)$ \\
\hline Cruiser (10) + Tefluthrin (10) & 15 & $25.7(4.4)$ & $18.0(2.2)$ & $27.7(7.3)$ & $48.0(9.6)$ & $71.3(14.8)$ \\
\hline Cruiser (15) + Tefluthrin (15) & 13 & $20.8(2.3)$ & $15.4(3.1)$ & $17.3(2.8)$ & $40.4(9.2)$ & $71.9(18.9)$ \\
\hline
\end{tabular}

Cruiser $=$ Cruiser 350FS, Tefluthrin = Tefluthrin 20CS. Numbers in parentheses indicate grams a.i. $100 \mathrm{~kg}^{-1}$ seed

${ }^{2} \mathrm{C}=$ number of wireworms that made three contacts. 


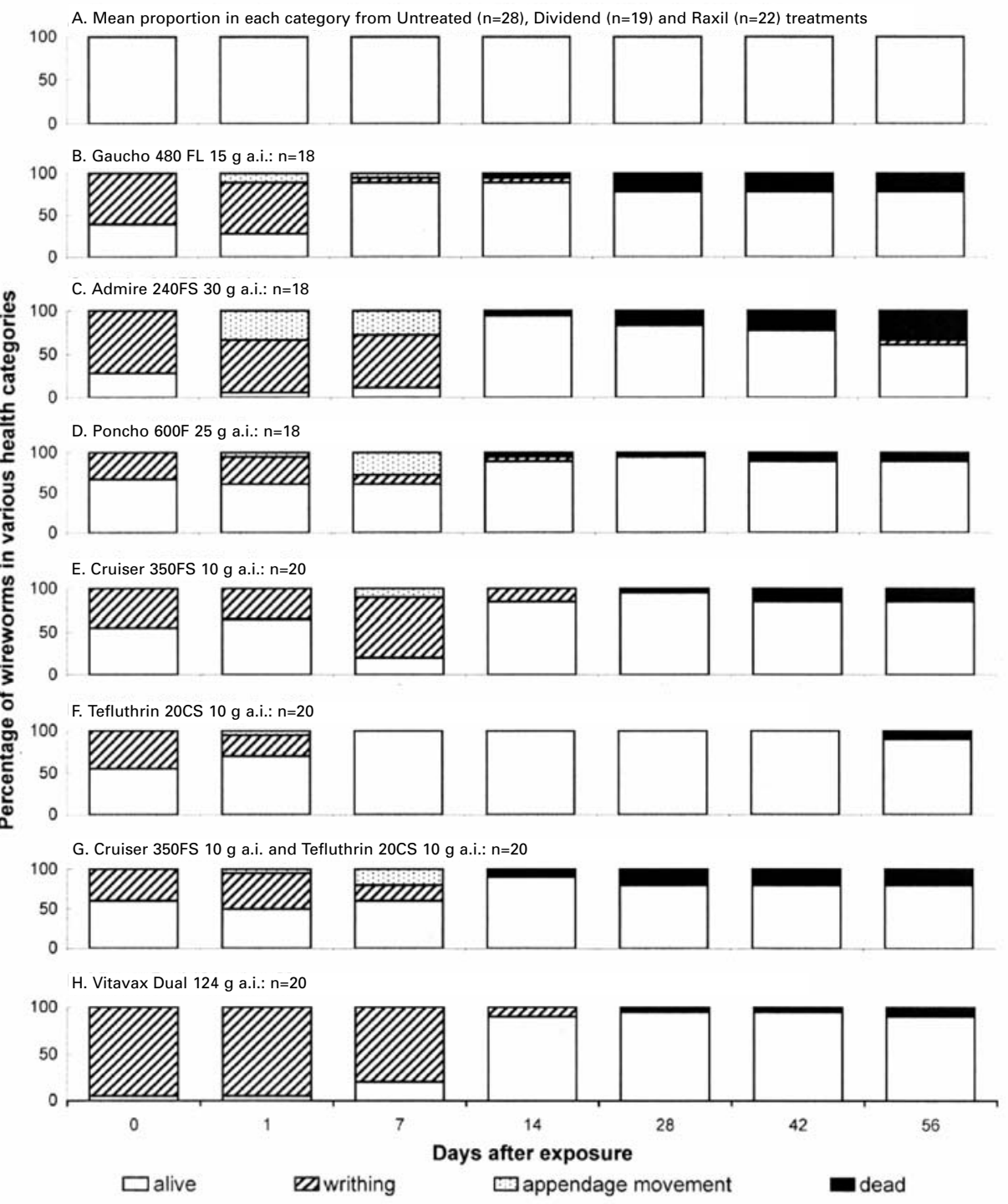

Figure 1. Health of Agriotes obscurus larvae 0, 1, 7, 14, 28, 42 and $56 \mathrm{~d}$ after exposure (DAE) to insecticide-treated wheat seeds during 180-min observation periods in a soil-window bioassay; 2005 study. See text for an explanation of wireworm health categories.

There were also significant differences in the proportion of $L$. canus wireworms dead at $70 \operatorname{DAE}\left(X^{2}=\right.$ $157.04, \mathrm{df}=15, P<0.0001)$ in 2006.

Control treatments

Morbidity and mortality were not observed in $A$. were exposed to control treatments (Table 1). Similarly, no morbidity and very low mortality was observed in $L$. canus larvae exposed to control treatments in the 2006 study (Table 2).

\section{Tefluthrin $20 S C$}

Morbidity of both $A$. obscurus and L. canus in the 2005 studies was low $(<50 \%)$ after bioassays with Tefluthrin and Tefluthrin plus Cruiser (Table 1), and all moribund wireworms had fully recovered by 7 DAE. Recovered wireworms did not subsequently relapse into morbidity, and no mortality occurred (Table 1 , Figs. 1 and 2). Similarly, in the 2006 study, nearly all L. canus larvae that were moribund at the end of the observation period after bioassays with Tefluthrin or Tefluthrin plus Cruiser had fully recovered by 3 DAE (Fig. 3), only causing low (or zero) mortality in all treatments containing Tefluthrin (Table 2). Wireworms in all treatments containing Tefluthrin were often observed to be 'writhing' after contact at some point during the observation period, but turned out to be 'alive' when checked at the end of the observation period (data not shown).

\section{Cruiser 350FS}

Considerably more $A$. obscurus larvae were moribund after bioassays with Cruiser at $10 \mathrm{~g}$ a.i. than at $30 \mathrm{~g}$ a.i. (Table 1), but nearly all wireworms made a full recovery by 14 DAE (Fig. 1). Despite the high per- 
A. Mean proportion in each category from Untreated $(n=20)$, Dividend $(n=10)$ and Raxil $(n=10)$ treatments

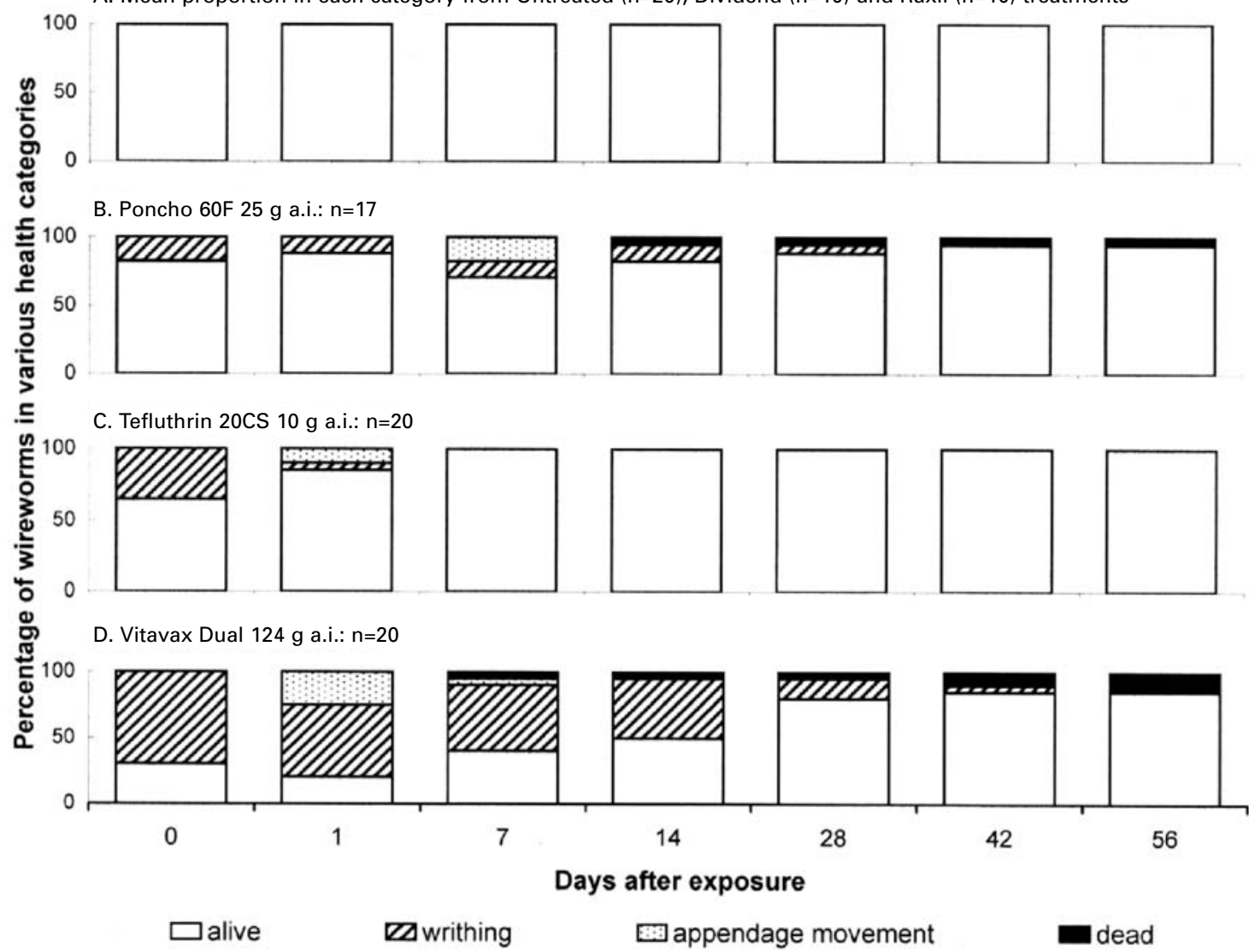

Figure 2. Health of Limonius canus larvae 0, 1, 7, 14, 28, 42 and $56 \mathrm{~d}$ after exposure (DAE) to insecticide-treated wheat seeds during 180-min observation periods in a soil-window bioassay; 2005 study. See text for an explanation of wireworm health categories.

centage $(90 \%)$ of moribund larvae, mortality was low in the $10 \mathrm{~g}$ a.i. treatment, while there was no mortality in the $30 \mathrm{~g}$ a.i. treatment (Table 1). A smaller proportion of $A$. obscurus larvae were moribund, but a slightly greater proportion died after bioassays with the Cruiser and Tefluthrin combination than after bioassays with either chemical at $10 \mathrm{~g}$ a.i. singly (Table 1).

In the 2006 study, no L. canus larvae were moribund after exposure to Cruiser at $5 \mathrm{~g}$ a.i. or Cruiser plus Tefluthrin at $20 \mathrm{~g}$ a.i., and only a low percentage $(<40 \%)$ of wireworms were moribund in all other Cruiser (plus Tefluthrin) treatments (Table 2). Wireworms that were moribund after exposure to Cruiser (all concentrations) had fully recovered by $14 \mathrm{DAE}$, but a considerable percentage (25-75\%) relapsed thereafter and had died by 70 DAE (Fig. 3; Table 2).

Mortality in Cruiser treatments increased with concentration (data for Cruiser at $20 \mathrm{~g}$ a.i. were excluded from the analysis due to concerns regarding seed appetence, as discussed above). Mortality was significantly lower in bioassays with Tefluthrin plus Cruiser than in bioassays with Cruiser alone at the same rates.
Vitavax Dual

A high percentage of larvae of $A$. obscurus (100\%) and $L$. canus $(68 \%)$ in the 2005 studies were moribund after bioassays with Vitavax Dual (Table 1), but nearly all moribund wireworms had fully recovered by 28 DAE (Figs. 1 and 2). Similarly, a high percentage $(74 \%)$ of $L$. canus larvae were moribund after bioassays with Vitavax Dual (Table 2), but all had fully recovered by $14 \mathrm{DAE}$ and did not relapse subsequently, causing no mortality in this treatment (Table 2, Fig. 3).

\section{Other treatments}

A high percentage ( $>70 \%$ ) of $A$. obscurus larvae were moribund after bioassays with Admire 240FS, Gaucho 480FL and Poncho 600F (Table 1), but nearly all moribund wireworms in these treatments had fully recovered by $14 \mathrm{DAE}$ (Fig. 1). However, some wireworms exposed to Admire and Gaucho relapsed and died 14 DAE (Fig. 1). Wireworm morbidity and mortality after contact with Poncho was similar for L. canus and $A$. obscurus in the 2005 studies (Table 1, Figs. 1 and 2). 


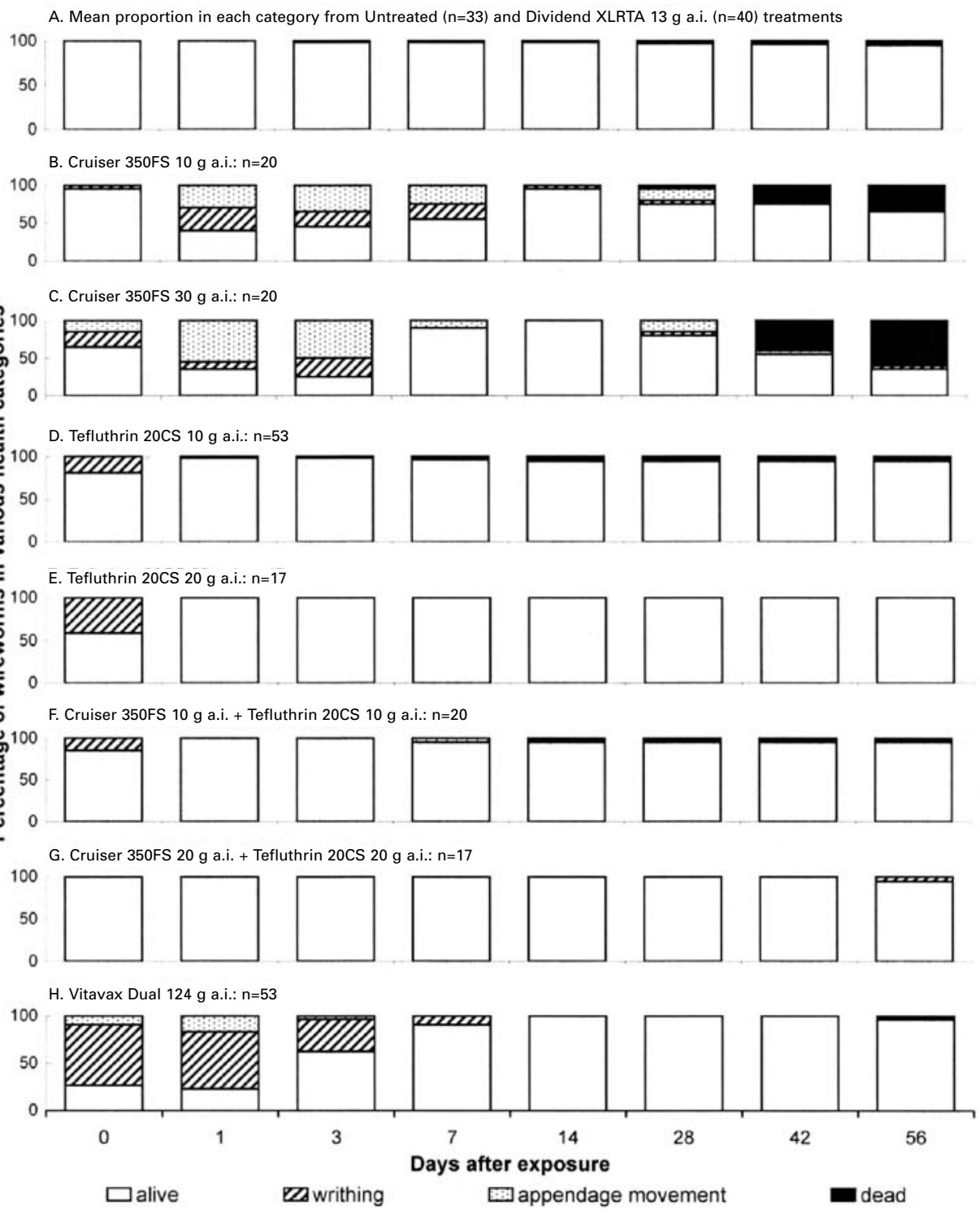

Figure 3. Health of Limonius canus larvae $0,1,3,7,14,28,42$ and $56 \mathrm{~d}$ after exposure (DAE) to insecticide-treated wheat seeds during 300-min observation periods in a soil-window bioassay; 2006 study. See text for an explanation of wireworm health categories.

\section{DISCUSSION}

\section{Evaluation of insecticide treatments} Control treatments
Tefluthrin 20SC

Both $A$. obscurus and $L$. canus were strongly repelled by Tefluthrin. At all concentrations tested, wireworms only came into contact with treated seeds briefly before moving away. While brief contact induced morbidity in some wireworms, nearly all recovered fully and there was little mortality in either species. Both the low mortality and rapid recovery (without relapse) of $A$. obscurus and $L$. canus following Tefluthrin-induced morbidity are similar to previous observations in which $L$. canus larvae had been exposed to treated wheat seeds in Eppendorf tubes (van Herk and Vernon 2007b).

The similarity between first and second contact durations in both $A$. obscurus and $L$. canus exposed to Tefluthrin suggests that duration of the second 
contact was not affected by the previous contact (i.e. that wireworms were not repelled from the seeds more quickly), and that the larvae did not learn to avoid seeds treated with Tefluthrin. Since wireworms can become moribund within 5 min of contact with Tefluthrin and subsequently recover within 1-2 h (van Herk and Vernon 2007b), it is likely that wireworms observed to be 'writhing' after contact during bioassays with Tefluthrin were temporarily moribund from contact but had recovered before the end of the observation period.

Together these results indicate that Tefluthrin may be ineffective for reducing wireworm populations in the field, but may give stand protection in the field due to its repellence effect. Contrary to expectations, combining Tefluthrin with Cruiser reduced the efficacy of Cruiser by significantly reducing the duration of contact with seeds. Comparisons of post-contact health profiles between the Cruiser, Tefluthrin, and Tefluthrin plus Cruiser treatments (Fig. 3) indicate that wireworms exposed to both Tefluthrin and Cruiser responded in a similar way as those exposed to Tefluthrin alone.

\section{Cruiser 350FS}

Larvae of $A$. obscurus and $L$. canus were not repelled by Cruiser 350FS. While L. canus in the 2006 study moved away from seeds treated with Cruiser at 20 and $30 \mathrm{~g}$ a.i. more quickly than from seeds treated with Dividend, only a low proportion of larvae were moribund at the end of the observation period. The considerable mortality (increasing with concentration) in $L$. canus observed at all concentrations of Cruiser suggests that a 2-3 h contact suffices to kill wireworms. Agriotes obscurus exposed to Cruiser at $10 \mathrm{~g}$ a.i. remained in contact for a shorter period, became moribund more quickly, and experienced less mortality than $L$. canus exposed to the same rate. This result, along with the briefer contact period and lower morbidity of $A$. obscurus at 30 than at $10 \mathrm{~g}$ a.i., suggests that increasing the contact duration with Cruiser may increase wireworm mortality, and that increasing the concentration of Cruiser on wheat seeds may reduce contact duration in $A$. obscurus (possibly by accelerating the onset of morbidity). It also suggests that the optimum concentration of Cruiser for wireworm management may vary with wireworm species.

The difference in post-contact health and mortality between the Cruiser and Cruiser plus Tefluthrin treatments suggests that the reduced contact duration with seeds containing Tefluthrin reduced the amount of Cruiser absorbed either orally and/or dermally by the wireworms, and it therefore indicates that placing both insecticides on wheat seeds may be less effective for wireworm control than exposing wireworms to Cruiser alone.

\section{Vitavax Dual}

Lindane is thought to elicit repellence in some wireworm species, including in L. californicus, a species closely related to $L$. canus (Toba et al. 1988). However, while first contact duration for L. canus in the 2005 and 2006 studies was considerably shorter in the Vitavax Dual treaments than in the control treatments, neither $A$. obscurus nor $L$. canus were repelled by Vitavax Dual. Wireworms often remained in contact for $1 \mathrm{~h}$ or more, and most wireworms of both species became moribund in situ. Wireworms that moved away without becoming moribund often returned for subsequent contact(s). While most $A$. obscurus and $L$. canus were moribund by the end of the observation period, mortality was low both in 2005 and 2006, suggesting that wireworms may become moribund before ingesting and/or making contact with lethal doses of lindane. The difference in duration of the first contact between $L$. canus and $A$. obscurus exposed to Vitavax Dual may indicate that wireworm response to lindane differs among species.

\section{Other treatments}

Agriotes obscurus larvae were not repelled by Gaucho 480FL or Admire 240FS in the 2005 study, indicating that neither formulation of imidacloprid elicits repellence at the concentrations tested. In contrast, previous studies in open-air bioassays suggested that imidacloprid at high concentrations ( $>1 \%$ a.i. in water or acetone) was slightly repellent to $A$. obscurus (van Herk et al. 2008b). There were no significant differences in the proportion of moribund wireworms at the end of the observation period or dead at 56 DAE among the Admire and Gaucho treatments, suggesting that both formulations affected wireworm health similarly. As in the Cruiser 350FS treatments, the relapse and death after temporary recovery of A. obscurus exposed to Gaucho and Admire (Fig. 1) stress the importance of long-term post-contact health assessments.

Larvae of $A$. obscurus and $L$. canus were not repelled by Poncho 600F but contact with seeds was shorter than in all other insecticide treatments, except those containing Tefluthrin. Wireworms appeared to move away from treated seeds due to the onset of morbidity, and at the end of the observation period most wireworms that had come into contact with treated seeds were moribund. The subsequent low mortality in both wireworm species suggests that wireworms may become moribund before they can absorb lethal doses of insecticide. The similar response of $A$. obscurus to Poncho $600 \mathrm{~F}$ at $25 \mathrm{~g}$ a.i. and Cruiser $350 \mathrm{FS}$ at $30 \mathrm{~g}$ a.i. is of interest as insects metabolize the active ingredient of Cruiser (thiamethoxam) into clothianidin (the active ingredient in Poncho) (Nauen et al. 2003).

\section{Impacts of wireworm repellence and morbidity on insecticide effectiveness}

The results presented here indicate that contact with insecticide-treated seeds in the soil may cause morbidity in wireworms without causing subsequent mortality and that, consequently, long-term post-contact wireworm health checks are important for assessing an insecticide's efficacy. These results also indicate that wireworms will move towards seeds treated with insecticides but will often move away after contact. As an insect's internal state (e.g. concentration of nutrients or immune peptides in hemolymph) affects its behaviour (Miller and Strickler 1984; Pompilio et al. 2006; Riddell and Mallon 2006), it is probable that the onset of morbidity is the stimulus that elicits repellence in wireworms. Wireworms that moved away from insecticide-treated seeds often 
showed signs of morbidity later on, even if contact was very brief (i.e. in the tefluthrin treatments). Insecticides that cause a rapid induction of morbidity (e.g. tefluthrin) may not be effective for wireworm population control, as wireworms may be repelled before they can absorb toxic doses. While wireworms that are repelled may return for subsequent contact(s), repeated induction of morbidity by some insecticides (e.g. Tefluthrin) increases their ability to recover from morbidity (van Herk and Vernon 2007b). Furthermore, wireworms that become moribund after coming into contact with seeds treated with Poncho, Gaucho, Admire or Vitavax Dual may do so before ingesting enough insecticide to die. Since recovery from morbidity induced by these chemicals may continue for months (van Herk et al. 2008a; Vernon et al. 2008), wireworms returning to the same insecticidetreated plants that induced morbidity initially may not be affected once the plants are established (i.e. wheat and corn). Finally, while an insecticide that elicits repellence may permit crop establishment and provide stand protection, it may be ineffective for wireworm management, particularly if the crop matures in the soil (e.g. potatoes) and if wireworms return after the chemical's repellent effects have dissipated.

\section{Evaluation of bioassays}

The rapid orientation and high proportion of wireworms that came into contact with wheat seeds in these studies confirm that, contrary to what Chaton et al. (2008) suggested, wireworm host finding is nonrandom. Like many subterranean insect larvae, wireworms follow $\mathrm{CO}_{2}$ gradients to find their hosts in the soil (Doane et al. 1975; Guerenstein and Hildebrand 2008) and are able to detect the presence of a single germinating wheat seed in the soil from a $20 \mathrm{~cm}$ distance (Doane and Klinger 1978; Westcott et al. 1980). These characteristics have been used to develop effective bioassays for studying wireworm behaviour (e.g. Doane et al. 1975; Horton and Landolt 2002; van Herk and Vernon 2007a).

The results presented here also confirm that observing wireworm position and behaviour every 5 min is sufficient to assess contact and feeding behaviour (van Herk and Vernon 2007a), and they indicate that different insecticides elicit different behaviours in wireworms. However, as these observations were conducted under laboratory conditions over limited observation periods, the results presented here may not accurately reflect what occurs in the field. Increasing the number of seeds in the bioassay or the duration of observation periods will likely increase wireworm mortality in treatments in which wireworms became moribund in situ or continued to come into repeated contact with treated seeds.

\section{ACKNOWLEDGEMENTS}

We thank Leona Arnold for collecting A. obscurus larvae, Stu Reid and John Alcock for allowing us to collect $L$. canus larvae on their farms, and Markus Clodius for assistance with the figures. This work was supported by the Pesticide Risk Reduction and Minor Use Research Programs of Agriculture and Agri-Food Canada's Pest Management Centre.

\section{REFERENCES}

Andersch, W., and M. Schwarz. 2003. Clothianidin seed treatment (Poncho®)-the new technology for control of rootworms and secondary pests in US-corn production. Pflanzenschutz-Nachr. Bayer 56: 147-172.

Belcher, D.W., and F.D. Tenne. 1987. Elateridae larvae and control obtained with terbufos and phorate in first-year cornfields in Indiana. J. Kansas Entomol. Soc. 60: 127-132.

Bernays, E.A., and R. Chapman. 1987. Evolution of deterrent responses. Pages 159-174 in R. Chapman, E.A. Bernays and J.G. Stoffolano (eds.), Perspectives in Chemoreception and Behavior. Springer-Verlag, New York, USA.

Chaton, P.F., G. Lempérière, M. Tissut, and P. Ravanel. 2008. Biological traits and feeding capacity of Agriotes larvae (Coleoptera: Elateridae): A trial of seed coating to control larval populations with the insecticide fipronil. Pestic. Biochem. Physiol. 90: 97-105.

Dethier, V.G., L. Barton Browne, and C.N. Smith. 1960. The designation of chemicals in terms of the responses they elicit from insects. J. Econ. Entomol. 53: 134-136.

Doane, J.F., and J. Klinger. 1978. Location of carbon dioxide receptive sensilla on larvae of the wireworms Agriotes lineatus-obscurus and Limonius californicus. Ann. Entomol. Soc. Am. 71 : 357-363.

Doane, J.F., Y.W. Lee, J. Klinger, and N.D. Westcott. 1975. The orientation response of Ctenicera destructor and other wireworms (Coleoptera: Elateridae) to germinating grain and to carbon dioxide. Can. Entomol. 107: 1233-1252.

Grove, I.G., S.R. Woods, and P.P.J. Haydock. 2000. Toxicity of 1,3-dichloropropene and fosthiazate to wireworms (Agriotes spp.). Ann. Appl. Biol. 137: 1-6.

Guerenstein, P.G., and J.G. Hildebrand. 2008. Roles and effects of environmental carbon dioxide in insect life. Annu. Rev. Entomol. 53: 161-178.

Horne, P.A., and J.A. Horne. 1991. The life-history and control of Hapatesus hirtus Candeze (Coleoptera: Elateridae) in Victoria. Aust. J. Agric. Res. 42: 827-834.

Horton, D.R., and P.J. Landolt. 2002. Orientation response of Pacific Coast wireworm (Coleoptera: Elateridae) to food baits in laboratory and effectiveness of baits in field. Can. Entomol. 134: 357-367.

Kuhar, T.P., J. Speece III, J. Whalen, J.M. Alvarez, A. Alyokhin, G. Ghidiu, and M.R. Spellman. 2003. Current status of insecticidal control of wireworms in potatoes. Pestic. Outlook 14: 265-267.

Lockwood, J.A., T.C. Sparks, and R.N. Story. 1984. Evolution of insect resistance to insecticides: A re-evaluation of the roles of physiology and behavior. Bull. Entomol. Soc. Am. 30: 41-50.

Long, W.H., and J.H. Lilly. 1958. Wireworm behavior in response to chemical seed treatments. J. Econ. Entomol. 51: 291-295.

Maienfisch, P., M. Angst, F. Brandl, W. Fischer, D. Hofer, H. Kayser, W. Kobel, A. Rindlisbacher, R. Senn, A. Steinemann, and H. Widmer. 2001. Chemistry and biology of thiamethoxam: A second generation neonicotinoid. Pest Manag. Sci. 57 : 906-913.

Miller, J.R., and K.L. Strickler. 1984. Finding and accepting host plants. Pages 127-157 in W.J. Bell and R.T. Carde (eds.), Chemical Ecology of Insects. Chapman and Hall, London, UK.

Missionnier, J., and E. Brunel. 1979. Control tests against wireworms (Agriotes spp.) by broadcast and localized soil treatments: development of attacks on tubers, from treatment to harvest. Meded. Fac. Landbouwwet. Univ. Gent $44: 143-152$.

Nauen, R., U. Ebbinghaus-Kintscher, V.L. Saldago, and M. Kaussmann. 2003. Thiamethoxam is a neonicotinoid precursor converted to clothianidin in insects and plants. Pestic. Biochem. Physiol. 76: 55-69.

Parker, W.E., and J.J. Howard. 2001. The biology and management of wireworms (Agriotes spp.) on potato with particular reference to the U.K. Agric. Forest Entomol. 3: 85-98. 
Pompilio, L., A. Kacelnik, and S.T. Behmer. 2006. Satedependent learned valuation drives choice in an invertebrate. Science 311: 1613-1615.

Pons, X., and R. Albajes. 2002. Control of maize pests with imidacloprid seed dressing treatment in Catalonia (NE Iberian Peninsula) under traditional crop conditions. Crop Prot. 21: 943-950.

Ramsey, P.H. 1978. Power differences between pairwise multiple comparisons. J. Am. Stat. Assoc. 73: 363.

Riddell, C.R., and E.B. Mallon. 2006. Insect psychoneuroimmunology: Immune response reduces learning in protein starved bumblebees (Bombus terrestris). Brain Behav. Immun. 20 : 135-138.

Ryan, T.A. 1960. Significance tests for multiple comparisons of proportions, variances, and other statistics. Psychol. Bull. 57 : 318-323.

SAS Institute Inc. 2002. SAS/STAT User's Guide, Version 9.1. SAS Institute Inc., Cary, NC, USA.

Sparks, T.C., J.A. Lockwood, R.L. Byford, J.B. Graves, and B.R. Leonard. 1989. The role of behavior in insecticide resistance. Pestic. Sci. 26: 383-399.

Toba, H.H., K.S. Pike, and L.E. O'Keeffe. 1988. Carbosulfan, Fonofos, and Lindane wheat seed treatments for control of sugarbeet wireworm. J. Agric. Entomol. 5: 35-43.

van Herk, W.G., and R.S. Vernon. 2007a. Soil bioassay for studying behavioural responses of wireworms (Coleoptera: Elateridae) to insecticide-treated wheat seed. Environ. Entomol. 36: 1441-1449.

van Herk, W.G., and R.S. Vernon. 2007b. Morbidity and recovery of the Pacific Coast wireworm, Limonius canus, following contact with tefluthrin-treated wheat seeds. Entomol. Exp. Appl. 125: 111-117. van Herk, W.G., R.S. Vernon, J.H. Tolman, and H. Ortiz Saavedra. 2008a. Mortality of a wireworm, Agriotes obscurus (Coleoptera: Elateridae), following topical application of various insecticides. J. Econ. Entomol. 101: 375-383.

van Herk, W.G., R.S. Vernon, and B.D. Roitberg. 2008b. Repellency of a wireworm, Agriotes obscurus L. (Coleoptera: Elateridae) upon exposure to synthetic insecticides in a soil-less bioassay. Environ. Entomol. 37 : 534-545.

Vernon, R.S. 2005. Aggregation and mortality of Agriotes obscurus (Coleoptera: Elateridae) at insecticide-treated trap crops of wheat. J. Econ. Entomol. 98: 1999-2005.

Vernon, R.S., E. LaGasa, and H. Philip. 2001. Geographic and temporal distribution of Agriotes obscurus and $A$. lineatus (Coleoptera: Elateridae) in British Columbia and Washington as determined by pheromone trap surveys. J. Entomol. Soc. B.C. 98: 257-265.

Vernon, R.S., W.G. van Herk, J. Tolman, H. Ortiz Saavedra, M. Clodius, and B. Gage. 2008. Transitional sublethal and lethal effects of insecticides following dermal exposures to five economic species of wireworms (Coleoptera: Elateridae). J. Econ. Entomol. 101: 367-374.

Westcott, N.D., Y.W. Lee, and J.F. Doane. 1980. Determination of carbon dioxide production by Prairie grain wireworm and germinating wheat seeds using mass fragmentography. J. Econ. Entomol. 73: 561-563. 